\title{
Cezary Ritter
}

The John Paul II Institute at the Catholic University of Lublin, Poland

\section{The John Paul II Institute at the Catholic University of Lublin www.kul.Iublin.pl/ijp2 www.ethos.Iublin.pl}

The John Paul II Institute was founded by the decision of the Senate of the Catholic University of Lublin on June 25 1982. It is intended as "interdepartmental research and didactic unit" of the Catholic University of Lublin, dedicated to the study of "the thought of John Paul II and participation in the community of persons in the spirit of Christ's teaching as preached by the John Paul II" (an extract from the Statue of the Institute). Since October of 2010, the Institute has been operating within the Department of Philosophy of the Catholic University of Lublin.

The initiator of the Institute was Rev. Prof. Tadeusz Styczeń, the disciple and successor of Karol Wojtyła to the Chair of Ethics at the Catholic University in Lublin, and a close associate of Pope John Paul II. Rev. Styczeń served as director of the Institute for nearly a quarter of a century.

The activities of the Institute concentrate on the philosophy and theology of man and morality, as well as on the apostolic mission of Pope John Paul II, paying special attention to the defense of human life, the promotion marriage and the unity of family. The Institute pursues its aims by annual research international symposia, research and didactic activities - the latter in the forms of organized seminars, and also by editorial work. In 1988 the quarterly "Ethos" was founded taking the philosophical, theological, and current cultural issues in relation to the thought of Karol Wojtyła - John Paul II (each issue of "Ethos" is a monograph). The Institute also publishes a series of books: "John Paul II teaches" (theological and philosophical comments on the papal teachings): "Man and morality" (philosophical works of Karol Wojtyła), and "Pope Wojtyla's ministry of thinking" (monographs of contemporary authors on the philosophical and theological thought of Karol Wojtyła - John Paul II). 
The John Paul II Institute comprises the Research Council now chaired by Rev. Prof. Andrzej Szostek, the Board of the Institute, Director, Rev. Prof. Alfred M. Wierzbicki. 